\title{
АКТУАЛЬНЫЕ ПРОБЛЕМЫ И ПЕРСПЕКТИВЫ РАЗВИТИЯ НОВОЙ МОДЕЛИ АСПИРАНТУРЫ
}

\author{
Капшутарь М. А., Кандидат педагогических наук, доцент, заместитель начальника \\ Управления подготовки кадров высшей квалификаиии ФГБОУ ВО «Уральский \\ государственный медииинский университет», Россия \\ DOI: https://doi.org/10.31435/rsglobal_conf/25112020/7253
}

\begin{abstract}
This paper considers the state of training of personnel of higher qualification in postgraduate studies in the conditions of changing its place in the system of Russian education. Discussion issues discussed in the scientific environment related to the search for a new understanding of the purpose of modern postgraduate studies, the definition of its main functions are analyzed. The main approaches to determining the purpose of postgraduate studies are considered. Requirements to the structure and content of the educational program of postgraduate studies were analyzed. The relevance of development of various models of implementation of training of personnel of higher qualification is shown.

Keywords: postgraduate studies, scientific and pedagogical personnel, efficiency of postgraduate studies, federal state educational standard, basic professional educational program, professional standard, competences, professional culture of a postgraduate student.
\end{abstract}

Введение. «Закон об образовании в Российской Федерации» (273-ФЗ от 29.12.2012 г.) качественно изменил статус аспирантуры и ее место в системе образования, преобразовав ее из послевузовского в третий уровень высшего образования. Отнесение аспирантуры к основным профессиональным образовательным программам высшего образования в качестве его третьего уровня, находится в русле международной стандартной классификации уровней высшего образования и соответствует практике его реализации в Европе. Образовательный процесс в аспирантуре ведется в соответствии с Федеральными государственными образовательными стандартами (ФГОС аспирантуры) по направлениям подготовки. В процессе обучения аспиранты выполняют учебный план, проходят практики и промежуточную, а конце обучения государственную итоговую аттестацию, формами которой являются государственный экзамен и научный доклад об основных результатах подготовленной научно-квалификационной работы (диссертации), при успешном прохождении которой получают диплом об окончании аспирантуры с присвоением квалификации «Исследователь». «Преподаватель-исследователь». Также приняты нормативно-правовые акты, регламентирующие порядок приема в аспирантуру и порядок проведения государственной итоговой аттестации. Образовательные программы аспирантуры подлежат не только лицензированию, но и аккредитации.

Цель работы заключается в анализе состояния подготовки кадров высшей квалификации, определении проблемного поля современной аспирантуры в условиях изменения ее места в системе российского образования, актуализации проблемы конкурентоспособности выпускника аспирантуры на рынке труда и выявлении тех компетенций, которые значимы и востребованы данным рынком труда.

Материалы и методы связаны с анализом дискуссионных вопросов, обсуждаемых в научной среде, связанных с поиском нового понимания цели современной аспирантуры, определением ее основных функций; рассмотрением основных подходов к определению цели аспирантуры. Проанализированы требования к структуре и содержанию образовательной программы аспирантуры. Показана актуальность разработки различных моделей реализации подготовки кадров высшей квалификации.

Результаты исследования. Изменение статуса аспирантуры вызывает многочисленные дискуссии в академической среде $[19 ; 15 ; 12 ; 17 ; 8]$. Исследователи, анализируя первые результаты реформирования аспирантуры, отмечают неоднозначность указанных нововведений.

Так, в заявлении Совета по науке при Министерстве образования и науки РФ от 31.03.2016 г. отмечается, что переход аспирантуры с уровня послевузовской подготовки на уровень высшего образования был «осуществлен механически, без учета особенностей аспирантуры как системы подготовки научно-педагогических кадров». Авторы говорят о 
недостаточной проработанности, нормативно-правовой неопределенности, внутренней противоречивости современной модели аспирантуры, связанной, прежде всего, с процедурой государственной итоговой аттестации аспирантов. Так, программа подготовки аспирантов, регулируемая ФГОС, не включает обязательную подготовку и защиту кандидатской диссертации. Также отмечается несовершенство механизмов финансового сопровождения реформы, что не позволяет большинству образовательных организаций реализовывать инновационные программы аспирантуры, а традиционная дисциплинарная структура предоставляемых финансовых ресурсов (контрольные цифры приема) не соответствует ни мировым трендам, ни структуре российских исследований и разработок [5].

Таким образом, очевидно, что в связи с изменением статуса аспирантуры необходим поиск новых подходов к содержанию образовательной программы аспирантуры, обеспечивающей эффективную подготовку кадров высшей квалификации.

Если определить наиболее дискуссионные проблемы в деятельности современной аспирантуры, то исследователи [16] выделяют три блока вопросов.

Прежде всего, речь идет о понимании цели современной аспирантуры и ее основных функций. Традиционная функция аспирантуры - подготовка научных и научно-педагогических кадров - уже не является ее единственной функцией, так как, по результатам проведенного исследования, лишь 54\% аспирантов планируют после окончания аспирантуры строить академическую карьеру. Почти половина выпускников нацелены на построение профессиональной карьеры в других сферах - в бизнесе, государственном управлении и сфере услуг.

Анализ исследований данной проблемы $[1 ; 15]$ позволяет говорить о трех основных оформившихся в научной литературе подходах к пониманию целей аспирантской подготовки:

- «диссертационный подход», который целью аспирантуры считает систематическую целенаправленную научно-исследовательскую работу аспирантов и как ее результат обязательную защиту кандидатской диссертации. Образовательная же составляющая программы аспирантской подготовки, значительно усиленная в новой ее модели, в данном контексте, отвлекает аспирантов от подготовки диссертации;

- «образовательный подход», рассматривающий аспирантуру, прежде всего, как образовательную программу третьего уровня высшего образования со всеми ее обязательными атрибутами - учебным планом, календарным учебным графиком, дисциплинами и модулями, практиками, промежуточной и государственной итоговой аттестацией, присвоением квалификации «Исследователь. Преподаватель-исследователь». Защита кандидатской диссертации не закреплена в ФГОС направлений подготовки в аспирантуре, следовательно, не является целью аспирантской подготовки;

- «квалификационный подход», который можно считать неким компромиссом между двумя вышеобозначенными подходами. Сторонники данного подхода считают, что у будущих работодателей выпускников аспирантуры будут востребованы, в первую очередь, не кандидаты наук, а специалисты, овладевшие за время аспирантской подготовки уникальными профессиональными, исследовательскими и аналитическими компетенциями. Поэтому, по их мнению, в аспирантуре должен быть грамотно организован образовательный процесс, в котором подготовка диссертации является важнейшей, но не единственной задачей.

В последнее время речь идет о низкой эффективности работы аспирантуры, актуализируются серьезные проблемы в ее деятельности. Исследователи говорят о серьезном кризисе российской аспирантуры, акцентируя на некоторых его проявлениях:

- падение интереса, снижение мотиваций и стимулов к профессиональной научной деятельности у молодежи [19, с.22-23];

- невыполнение аспирантурой традиционно возлагаемой не нее функции воспроизводства кадрового потенциала науки и высшей школы, и обусловленное этим старение кадрового состава высшего образования и науки [6];

- снижение научного уровня диссертаций и сокращение доли выпускников, завершивших обучение с защитой диссертации [2, с.58]. Показателем результативности деятельности аспирантуры считается удельный вес лиц, защитивших диссертации в общей численности выпускников;

- серьезное снижение количества присуждаемых ученых степеней, а также их девальвация [3]; 
- «массовизация» аспирантуры. В сравнении с периодом СССР, когда аспирантура выполняла роль элитной, штучной подготовки кадров для высшей школы и науки, на сегодняшний день аспирантура стала полноценным сегментом рынка образовательных услуг [2, с.56]. По нашему мнению, «массовизацию» аспирантуры нельзя рассматривать как однозначно негативное явление, так как обучение значительного количества аспирантов в любом случае ведет к приращению совокупного интеллектуального потенциала страны.

Вторым серьезным дискуссионным вопросом является понимание структуры и содержания образовательного процесса в аспирантуре. После вступления в силу ФГОС аспирантуры образовательные организации столкнулись с проблемой необходимости разработки образовательной программы подготовки кадров высшей квалификации. Казалось бы, ФГОС дает ответы на все вопросы о структуре и содержании основной профессиональной образовательной программы (ОПОП). Так, структура ОПОП аспирантуры представлена обязательной (базовой) и вариативной частями. Что касается содержания, то ОПОП содержит 4 блока: дисциплины (модули); практики; научные исследования; государственная итоговая аттестация.

Однако, в условиях отсутствия примерных образовательных программ, исследователи [11] говорят о необходимости разработки различных моделей реализации подготовки кадров высшей квалификации. В качестве одного из вариантов предлагается универсальноориентированная образовательная программа [4].

Основными признаками универсальной модели, не зависимо от направления подготовки и сроков обучения, являются:

- доминирование научной направленности образовательной программы над образовательной, ее цель - подготовка диссертации;

- обретение аспирантами нового статуса - обучающихся, учет новых условий их обучения; аспирантуры;

- преемственность образовательных программ магистратуры (специалитета) и

- акцент на личностное развитие аспиранта, на создание условий для реализации его исследовательского потенциала [12].

Выделим основные требования к универсальной модели образовательной программы аспирантской подготовки.

Так, основные элементы ОПОП аспирантуры - учебный план и календарный учебный график - должны отличаться от бакалаврских планов и графиков своей большей научной направленностью. При разработке содержания ОПОП необходим учет требований профессиональных стандартов. Так как основными видами профессиональной деятельности выпускников аспирантуры являются, в соответствии с ФГОС, педагогическая и научная деятельность, значительное внимание должно быть уделено практикам по получению профессиональных умений и опыта профессиональной деятельности. Программы практик следует соотносить с требованиями профстандартов [7]. Так, педагогическая практика, которая является обязательной, должна обеспечить выполнение обобщенной трудовой функции восьмого уровня квалификации профстандарта - «Преподавание по программам бакалавриата, специалитета, магистратуры и дополнительной профессиональной подготовки» [13]. Что касается научноисследовательской практики, то она должна быть ориентирована на выполнение обобщенных трудовых функций шестого уровня квалификации профстандарта - «Проведение научноисследовательских и опытно-конструкторских разработок при исследовании самостоятельных тем и по тематике организации» [14]. Важнейшим элементом ОПОП являются научные исследования, которые должны выполняться постоянно на протяжении всего периода обучения аспиранта, а их результаты должны соответствовать требованиям, которые предъявляются к научноквалификационной работе (диссертации), что закреплено в пункте 6.5. ФГОС аспирантуры.

В качестве третьего дискуссионного вопроса в проблемном поле современной аспирантуры исследователи выделяют проблему оценки результатов обучения и, в целом, эффективности аспирантуры. Государственная итоговая аттестация аспирантов проходит в форме сдаче государственного экзамена, который носит междисциплинарный характер, и представления научного доклада об основных результатах подготовленной научноквалификационной работы (диссертации). Сама же диссертация и процедура ее защиты остаются за рамками процедуры государственной итоговой аттестации. 
На наш взгляд, немаловажным фактором в определении цели подготовки аспирантов и, соответственно, содержания образовательной программы аспирантуры является запрос рынка труда. Для кого же готовит кадры современная аспирантура? Исследователи составили рейтинг значимости рынков труда для выпускников аспирантуры. На первом месте в этом рейтинге профессорско-преподавательский состав вузов, на втором - научные сотрудники вузов и научно-исследовательских институтов, на третьем - руководители и менеджеры образовательных и научных организаций. Каждый из названных рынков труда требует сформированности значимых именно для него компетенций. Так, для рынка труда ППС наиболее значимыми являются компетенции в сфере использования приемов и технологий образовательной деятельности; компетенции в сфере научно-исследовательской деятельности; компетенции в сфере личностного саморазвития; этические и коммуникативные компетенции. Для рынка труда научных сотрудников: компетенции в сфере научно-исследовательской деятельности; компетенции в сфере личностного саморазвития; этические и коммуникативные и информационно-технологические; компетенции в сфере экспертно-аналитической деятельности. Для рынка труда руководителей и менеджеров образовательных и научных организаций: компетенции в сфере личностного саморазвития; этические, правовые, проектные и организационно-управленческие; компетенции в сфере финансовой и фандрайзинговой деятельности; коммуникативные компетенции [9].

Безусловно, основным рынком труда, на который ориентирована подготовка аспирантов, является профессорско-преподавательский состав вузов. Необходимо отметить, что на данном рынке труда в последние годы складывается достаточно неблагоприятная ситуация для выпускников аспирантуры. Анализ статистических данных показывает тенденцию сокращения количества рабочих мест преподавателей, как в целом, так и по отдельным должностям профессорско-преподавательского состава. Так, если в 2005/2006 учебном году численность ППС организаций высшего образования составляла 358,9 тыс. человек, то в 2018/2019 учебном году всего 236,1 тыс. человек. Данное обстоятельство, с одной стороны, порождает проблему трудоустройства выпускников, а с другой повышает конкуренцию на рынке труда, особенно с учетом роста выпуска аспирантов по социально-гуманитарным специальностям и вновь актуализирует проблему качества подготовки в аспирантуре.

Именно компетентностный подход в подготовке аспирантов становится условием повышения эффективности ее деятельности. Исследователи [10] описывают компетентностную модель подготовки аспирантов как совокупность трех основных блоков компетентностей: методологической, коммуникативной (иноязычной) и профессионально-педагогической. В связи с тем, что основное место в подготовке аспиранта занимает научно-исследовательская деятельность, а основным рынком труда для выпускников аспирантуры является профессорскопреподавательский состав организаций высшего образования, мы полагаем, что ведущим фактором, влияющим на качество и результаты этой деятельности, становится уровень методологической подготовки аспиранта.

В данном контексте в качестве результата высшего образования следует рассматривать профессиональную культуру ее выпускника, понимаемую как совокупность «...общечеловеческих идей, профессионально-ценностных ориентаций и качеств личности, универсальных способов познания и гуманистических технологий профессиональной деятельности» [18, с.4].

Исследователи выделяют в структуре профессиональной культуры следующие компоненты: гносеологический, связанный с интеллектуальной, методологической и исследовательской культурой; гуманистический, определяющий духовную и нравственную культуру; коммуникативный - рефлексивную, речевую и культуру общения; образовательный - методическую и дидактическую культуру; нормативный - управленческую и правовую культуру; информационный - инновационную, диагностическую, цифровую культуру [там же].

Выводы. Таким образом, разработка образовательной программы аспирантуры, адекватной новым условиям ее работы и учитывающей цели и потребности всех участников данного процесса, реализуемого на стыке образования, науки и бизнеса, является актуальной задачей педагогической науки и практики. Данная проблема перейдет из области теоретических изысканий в сферу практической реализации и будет решена только тогда, когда будут четко определены цель и конечные результаты деятельности российской аспирантуры. 
Это позволит оценивать эффективности ее работы. Оценка эффективности аспирантуры должна происходить по единым критериям и показателям.

В настоящее время исследования профессиональной культуры исследователей приобретает особую значимость, что обусловлено глобальными изменениями образовательного и социокультурного контекста. Перспективным направлением исследований может стать поиск критериев и показателей уровня сформированности профессиональной культуры аспиранта.

\section{ЛИТЕРАТУРА}

1. Бедный Б.И. К вопросу о цели аспирантской подготовки (диссертация vs квалификация) // Высшее образование в России. 2016. № 3. С. 44-52.

2. Бедный Б.И., Миронос А.А. Подготовка научных кадров в высшей школе. Состояние и тенденции развития аспирантуры. Монография. Н.Новгород: Изд-во ННГУ. 2008. 219 с.

3. Вершинин И.В. Развитие аспирантуры в России: решения в области повышения адресности отбора поступающих по программам подготовки кадров высшей квалификации // Наука. Инновации. Образование. 2015. № 18. С. 61-72.

4. Гвильдис Т.Ю. Опыт и результаты апробации универсально-ориентированной образовательной программы подготовки научно-педагогических кадров в аспирантуре // Ученые записки университета им. П.Ф. Лесгафта. № 2 (120). 2015. С. 38-43.

5. Гусев А.Б. Развитие аспирантуры в России: проблемы и решения // Наука. Инновации. Образование. 2015. № 17. C. 196-224.

6. Ключарев Г.А., Савенков А.И., Бакланов П.А. Кадры российской науки: проблемы и методы их решения // Социологические исследования. 2016. № 9. С. 117-125.

7. Методические рекомендации по разработке основных профессиональных образовательных программ и дополнительных профессиональных программ с учетом соответствующих профессиональных стандартов, утвержденные министром образования и науки РФ Д.В. Ливановым от 22.01.2015 №ДЛ-1/05вн.

8. Муратова Е.И., Дворецкий С.И., Иванов А.Ю. Особенности разработки учебного плана подготовки аспирантов // Высшее образование в России. 2015. № 2. С. 40-48.

9. Нечаев В.Д., Бродовская Е.В., Домбровская А.Ю., Карзубов Д.Н. Направления совершенствования программ аспирантуры по укрупненной группе специальностей и направлений «Образование и педагогические науки»: результаты экспертного опроса // Ценности и смыслы. 2016. № 5 (45). С. 10-32.

10. Никонова 3.В. Компетентностный подход в подготовке кадров высшей квалификации // Aspectus. 2014. № 1. C. 70-75.

11. Петров В.Л., Бабичев Ю.Е. Модели программы подготовки кадров высшей квалификации в аспирантуре // Высшее образование в России. 2017. № 7 (214). С. 5-14.

12. Попова Н.Г., Биричева Е.В. Подготовка молодых учёных в аспирантуре: поиск единого ориентира // Высшее образование в России. 2017. № 1. С. 5-14.

13. Профессиональный стандарт «Педагог профессионального обучения, профессионального образования и дополнительного профессионального образования», утвержденный приказом Министерства труда и социальной защиты Российской Федерации от 8 сентября 2015 г. № 608н.

14. Профессиональный стандарт «Специалист по научно-исследовательским и опытноконструкторским разработкам», утвержденный приказом Министерства труда и социальной защиты Российской Федерации от 4 марта 2014 г. № $121 \mathrm{H}$.

15. Райчук Д.Ю., Минина Н.В. О позиционировании аспирантуры в структуре высшего образования // Высшее образование в России. 2016. № 4. С. 33-40.

16. Рыбаков Н.В., Бедный Б.И. Проблемное поле в исследовании российской аспирантуры: образовательный и социологический подходы // Вестник Нижегородского университета им. Н.И. Лобачевского. Серия: Социальные науки, 2017, № 2 (46). С. 113-121.

17. Сенашенко В.С. Проблемы организации аспирантуры на основе ФГОС третьего уровня высшего образования // Высшее образование в России. 2016. № 3. С. 33-43.

18. Сластенин В.А. Стратегии модернизации высшего образования // Сибирский педагогический журнал. 2005. № 1. С. 3-13.

19. Шестак В.П., Шестак Н.В. Аспирантура как третий уровень высшего образования: дискурсивное поле // Высшее образование в России. 2015. № 12. С. 22-34. 